\title{
Senior high school track and strand preference using the SOAR Intervention Program
}

\author{
Maurice Dence Bacaling \\ mauricedence.bacaling@deped.gov.ph \\ Sta. Cruz National High School, Sta. Cruz Davao del Sur, Philippines \\ https://orcid.org/0000-0002-9505-8488
}

Pilarica T. Dizon

pilarica.dizon@deped.gov.ph Sta. Cruz National High School, Sta. Cruz Davao del Sur, Philippines https://orcid.org/0000-0003-3688-914X

Laarni T. Orpilla

laarni.orpilla@deped.gov.ph Sta. Cruz National High School, Sta. Cruz Davao del Sur, Philippines https://orcid.org/0000-0003-2606-1154

\begin{abstract}
The purpose of this study was to examine the students' track and strand preferences after the SOAR (Student Orientation, Awareness, and Redirection) Intervention Program. This action research employed the descriptive quantitative research design using a researcher-made survey questionnaire that were administered to Grade 10 students from Santa Cruz National High School - Junior High School $(n=319)$ and Manuel Francisco C. Ramos Sr. National High School $(n=64)$. Frequency, percentage and ranking were utilized as statistical tool for this study. Results revealed that the majority of respondents opted to enroll at Sta. Cruz National High School - Senior High School. The Humanities and Social Science strand under the Academic Track had the largest number of students who favoured it over the other strands. Furthermore, it was clear that the majority of them chose the Technical Vocational Track over the Academic Track. The findings can be used to improve Career Guidance in the school, especially parents' engagement in their children's career decisions. Similarly, it is suggested that a standardized enrolment process be developed in which students undergo career assessments in order to help direct them in deciding which strand to pursue.
\end{abstract}

Keywords: Career, Track, Strand, preference, descriptive-quantitative, Philippines

\section{RESUMEN}

El propósito de este estudio fue examinar las preferencias de seguimiento y hebra de los estudiantes después del Programa de Intervención SOAR (Orientación, Conciencia y Redirección del Estudiante). Esta investigación de acción empleó el diseño de investigación descriptiva cuantitativa utilizando un cuestionario de encuesta elaborado por investigadores que se administró a los estudiantes del décimo grado de la Escuela Secundaria Nacional Santa Cruz Escuela Secundaria $(n=319)$ y la Escuela Secundaria Nacional Manuel Francisco C. Ramos Sr. ( $n=64)$. La frecuencia, el porcentaje y la clasificación se utilizaron como herramienta estadística para este estudio. Los resultados revelaron que la mayoría de los encuestados optaron por inscribirse en Sta. Cruz National High School - Escuela secundaria superior. La rama de Humanidades y Ciencias Sociales de la Sección Académica tuvo el mayor número de estudiantes que la favorecieron sobre las otras ramas. Además, estaba claro que la mayoría de ellos eligió la Vía Técnica Vocacional sobre la Vía Académica. Los resultados se pueden utilizar para mejorar la orientación profesional en la escuela, especialmente la participación de los padres en las decisiones profesionales de sus hijos. De manera similar, se sugiere que se desarrolle un proceso de inscripción estandarizado en el que los estudiantes se sometan a evaluaciones de carrera para ayudarlos a decidir qué línea seguir.

Palabras clave: carrera, trayectoria, rama, preferencia, descriptivo-cuantitativo, Filipinas

\section{RESUMO}

O objetivo deste estudo foi examinar as preferências de trilhas e vertentes dos alunos após o Programa de Intervenção SOAR (Orientação, Conscientização e Redirecionamento do Aluno). Esta pesquisa-ação empregou o desenho de pesquisa quantitativa descritiva usando um questionário de pesquisa feito por um pesquisador que foi administrado a alunos da $10^{a}$ série da Escola Nacional de Santa Cruz - Escola Secundária $(n=319)$ e da Escola Secundária Manuel Francisco C. Ramos Sr. ( $n=64)$. Frequência, porcentagem e classificação foram utilizadas como ferramenta estatística para este estudo. Os resultados revelaram que a maioria dos entrevistados optou por se inscrever no Sta. Cruz National 
High School - Senior High School. A vertente Humanidades e Ciências Sociais do Percurso Académico teve o maior número de alunos que a favoreceram em relação às outras vertentes. Além disso, ficou claro que a maioria deles optou pelo Percurso Profissional Técnico em detrimento do Percurso Acadêmico. Os resultados podem ser usados para melhorar a Orientação Profissional na escola, especialmente o envolvimento dos pais nas decisões de carreira de seus filhos. Da mesma forma, sugere-se o desenvolvimento de um processo de matrícula padronizado, no qual os alunos passam por avaliações de carreira, a fim de orientá-los na decisão de qual vertente seguir.

Palavras-chave: Carreira, Track, Strand, preferência, descritivo-quantitativo, Filipinas

\section{INTRODUCTION}

One of the challenges of a Grade 10 student after completing the Junior High School is to decide on what track and strand to take in the Senior High School. Although the Department of Education (DepEd) has already implemented the Career Guidance Program (Education, 2015) to Grade 10 students, there is still a need to reinforce the students in career decision making.

Furthermore, the Senior High School program has been in its third year of implementation for this school year 2018 - 2019. It is noticeable from the senior high school enrolment trends way back from school year 2016 - 2017 up to the present that there is a gradual increase in the enrolment for senior high school in Sta. Cruz National High School both Academic and Technical Vocational Track. Eight percent (8\%) has increased of the total enrolment from SY $2016-2017$ to SY 2017 - 2018. While 39\% has increased in the total enrolment from SY 2017 - 2018 up to present. Moreover, the enrolment trends also shown that there is an increase in the technical vocational track while the academic track has a fluctuating enrolment.

With this unexpected increase of enrolees in the Senior High School program for school year 2018 - 2019 and problems such as shifting to other strand, transferring to other school, dropped-out students and students at risk of dropping out (SARDO).

Thus, SOAR (Student Orientation, Awareness, and Redirection) Intervention program was proposed to be conducted to Grade 10 students in order to prevent the possible existing problem to happen for the incoming school year $2019-2020$.

\section{Statement of the Problem}

This baseline study sought to find out the students' track and strand preferences after the SOAR intervention program. It answers the following specific questions:

1. What is the students' demographic profile in terms of:

1.1 current programs enrolled;

1.2 gender;

1.3 age?

2. What is the students' preferred track and strand after the SOAR?

3. What is the students' preferred school after the SOAR?

\section{THEORITICAL FOUNDATION}

This research was based on Frank Parsons' theory. Every individual has their own set of interests and skills, and different jobs (and specialties) have different ability and personality requirements. If a person with specific interests and skills can find a job that matches those interests and requires his skills, it appears that the person is well suited to the job. Person-environment fit theories are basically a career-matching approach to career development (Parsons, 1909). 
In addition, group engagement theories explain how psychological and sociological variables affect career choices. Law (1981) explains how the society in which a person lives and works can inspire him to pursue a specific career goal, or how it can fail to do so, in his Community Interaction Theory. In this context, the group refers to all of the people with whom an individual communicates, including spouses, relatives, friends, co-workers, and others. We constantly listen to and take advice from such people: their advice is valuable to us, and it matters. Making important career decisions without the input of such influential people can be challenging, and it can make any career decision more difficult.

\section{METHODOLOGICAL PROCEDURES}

This chapter presented the design, respondents and sampling, data collection procedure, and data analysis.

\subsection{Research Design}

This action research employed the descriptive quantitative research design (Nuñez, 2015). In context, this research examined the students' track and strand preferences after the SOAR intervention program using a researcher-made survey questionnaire.

\subsection{Respondents and Sampling}

A purposive sampling was employed in the selection of the sample size. The main research respondents were the Grade 10 students from Santa Cruz National High School - Junior High School and Manuel Francisco C. Ramos Sr. National High School, school year 2018 - 2019.

\subsection{Data Gathering Procedure}

The researchers wrote a permission letter to the principal asking for the consent to conduct an action research. A letter was also sent to the office of the registrar requesting for the class list of Grade 10 classes. After the approval, the researchers conducted the SOAR Intervention Program to Grade 10 students in their respective classroom.

This SOAR Intervention Program covered the students' orientation wherein they undergone senior high school orientation including the different tracks and strand offered by the school. This orientation aimed to prepare the students of what would be the information needed when entering the senior high school. After which, the students answered the survey questionnaire.

\subsection{Data Analysis}

The collected data were treated using the following simple statistics, i.e., frequency, percentage and ranking.

\section{RESULTS AND DISCUSSION}

The results of the study are presented in this section.

\subsection{Profile of the Students}

Based on the data of curriculum program, majority of the respondent - students from both schools were from General Curriculum program with 82.8\%. While 10.7 percent were from Science $\&$ Technology and Engineering Program (STEP). In addition, the Special Program and Arts (SPA) 
got $6.3 \%$ of respondent-students. Lastly, the Special Program in Education (SPED) with 0.2\% of respondent-students.

Table 1. Profile of the students based on Curriculum Program

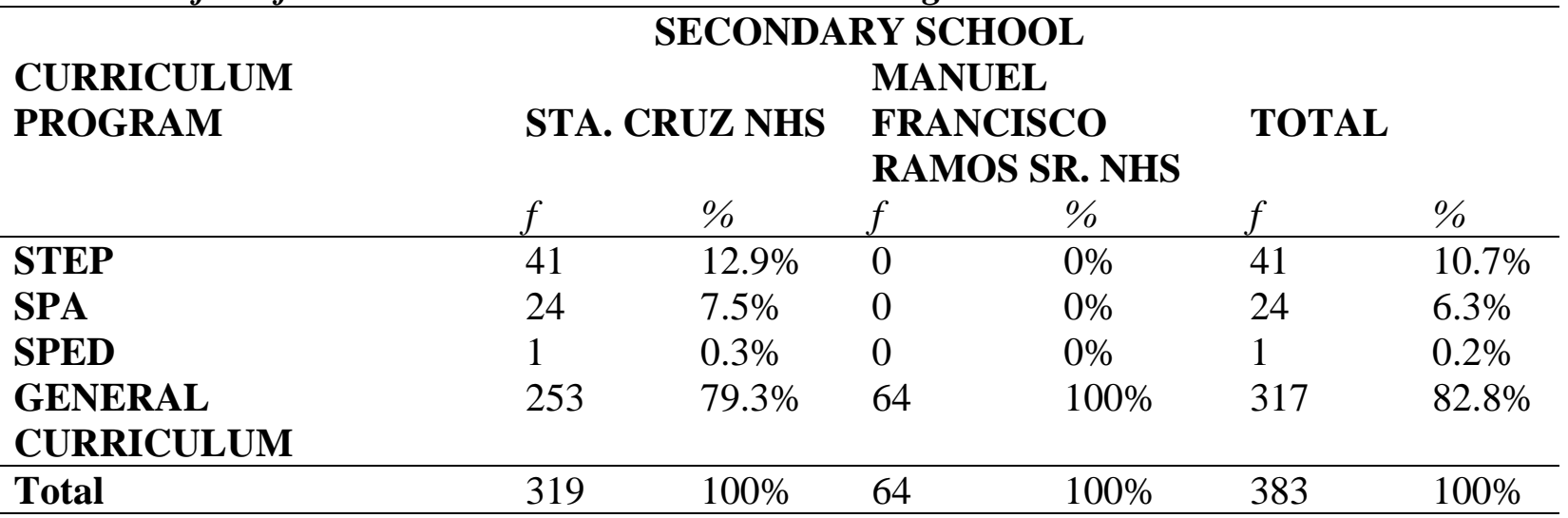

Table 2 presents the profile of the students based on gender, $59.3 \%$ were female and $40.4 \%$ were male students from Santa Cruz National High School. On the other hand, $57.8 \%$ were female and $42.2 \%$ were male students from Manuel Francisco Ramos Sr. National High School. Overall, majority of the respondent-students were female (59.3\%).

Table 2. Profile of the students based on Gender

SECONDARY SCHOOL

\begin{tabular}{|c|c|c|c|c|c|c|}
\hline \multirow[t]{2}{*}{ GENDER } & \multicolumn{2}{|c|}{ STA. CRUZ NHS } & \multicolumn{2}{|c|}{$\begin{array}{l}\text { MANUEL } \\
\text { FRANCISCO } \\
\text { RAMOS SR. NHS }\end{array}$} & \multicolumn{2}{|c|}{ TOTAL } \\
\hline & $f$ & $\%$ & $f$ & $\%$ & $f$ & $\%$ \\
\hline Male & 129 & $40.4 \%$ & 27 & $42.2 \%$ & 156 & $40.7 \%$ \\
\hline Female & 190 & $59.6 \%$ & 37 & $57.8 \%$ & 227 & $59.3 \%$ \\
\hline Total & 319 & $100 \%$ & 64 & $100 \%$ & 383 & $100 \%$ \\
\hline
\end{tabular}

Table 3 shows the age of the respondent-students involved in this study ranged from 15 to 22 years old. Students aged of $16(43.3 \%)$ were the highest number of participants of Santa Cruz National High School. While students aged of 15 (40.6\%) were the highest number of participants from Manuel Francisco Ramos Sr. National High School. Thus, for both schools, majority of the respondent-students were of age 16 with 42.6 percent.

Table 3. Profile of the students based on Age

\section{SECONDARY SCHOOL}

AGE

STA. CRUZ NHS FRANCISCO

TOTAL

RAMOS SR. NHS

\begin{tabular}{lllllll} 
& $f$ & $\%$ & $f$ & $\%$ & $f$ & $\%$ \\
\hline $\mathbf{1 5}$ & 122 & $38.3 \%$ & 26 & $40.6 \%$ & 148 & $38.6 \%$ \\
$\mathbf{1 6}$ & 138 & $43.3 \%$ & 25 & $39.1 \%$ & 163 & $42.6 \%$ \\
$\mathbf{1 7}$ & 36 & $11.3 \%$ & 8 & $12.5 \%$ & 44 & $11.5 \%$
\end{tabular}

Sapienza: International Journal of Interdisciplinary Studies | Vol. 2 | n. 2 | Abr-Jun | 2021 | e-ISSN: 2675-9780 


\begin{tabular}{lllllll}
$\mathbf{1 8}$ & 11 & $3.4 \%$ & 2 & $3.1 \%$ & 13 & $3.4 \%$ \\
$\mathbf{1 9}$ & 2 & $0.6 \%$ & 1 & $1.6 \%$ & 3 & $0.8 \%$ \\
$\mathbf{2 0}$ & 2 & $0.6 \%$ & 0 & $0 \%$ & 2 & $0.5 \%$ \\
$\mathbf{2 1}$ & 0 & $0 \%$ & 0 & $0 \%$ & 0 & $0 \%$ \\
$\mathbf{2 2}$ & 0 & $0 \%$ & 0 & $0 \%$ & 0 & $0 \%$ \\
Not Indicated & 8 & $2.5 \%$ & 2 & $3.1 \%$ & 10 & $2.6 \%$ \\
\hline Total & 319 & $100 \%$ & 64 & $100 \%$ & 383 & $100 \%$ \\
\hline
\end{tabular}

4.2. Student's Preferred Track and Strand

Most of the respondent-students of the study preferred Technical Vocational and Livelihood (TVL) track with a percentage of 54.3. On the other hand, 45.7 percent of the respondent-students would like to enroll in the Academic track as presented in Table 4.A.

Table 4A. Student's Preferred Track

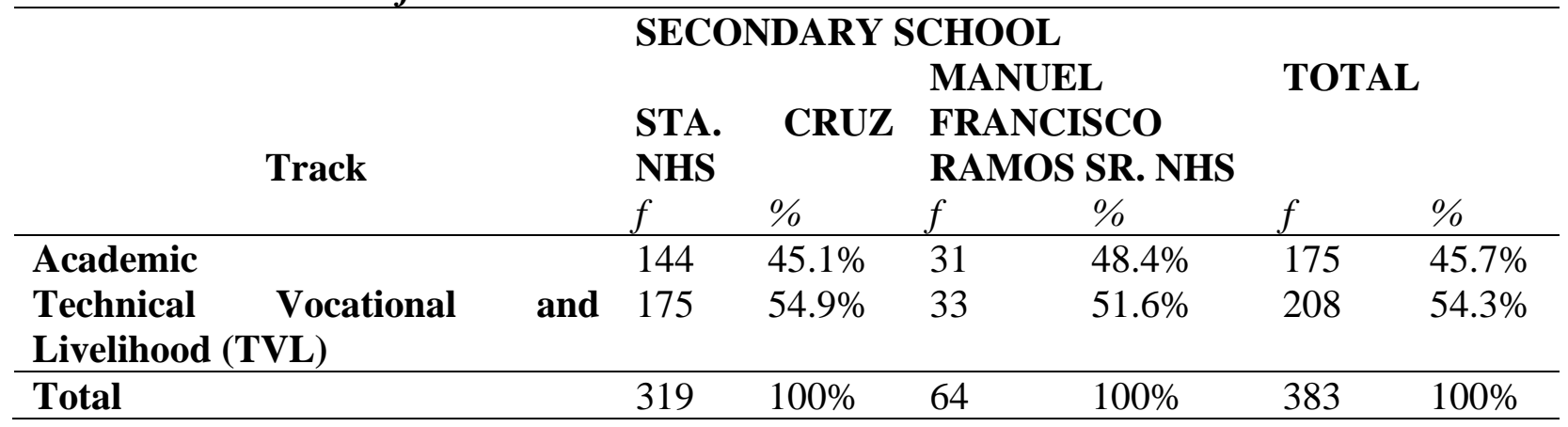

Table 4B shows the results of preferred strand that the students would like to take after completing the Junior High School, most of the respondent-students preferred to take Humanities and Social Science strand with $24.8 \%$, followed by Home Economics - Caregiving with 17\%, and Science and Technology, Engineering, and Mathematics (STEM) with 12\%. It was noticeable that no students preferred to take ICT - Computer Animation strand (0\%).

Table 4B. Student's Preferred Strand

\begin{tabular}{llll}
\multicolumn{2}{l}{ SECONDARY SCHOOL } & & \\
MANUEL & TOTAL & RANK \\
STA. CRUZ & FRANCISC \\
NHS & O RAMOS & & \\
& &
\end{tabular}

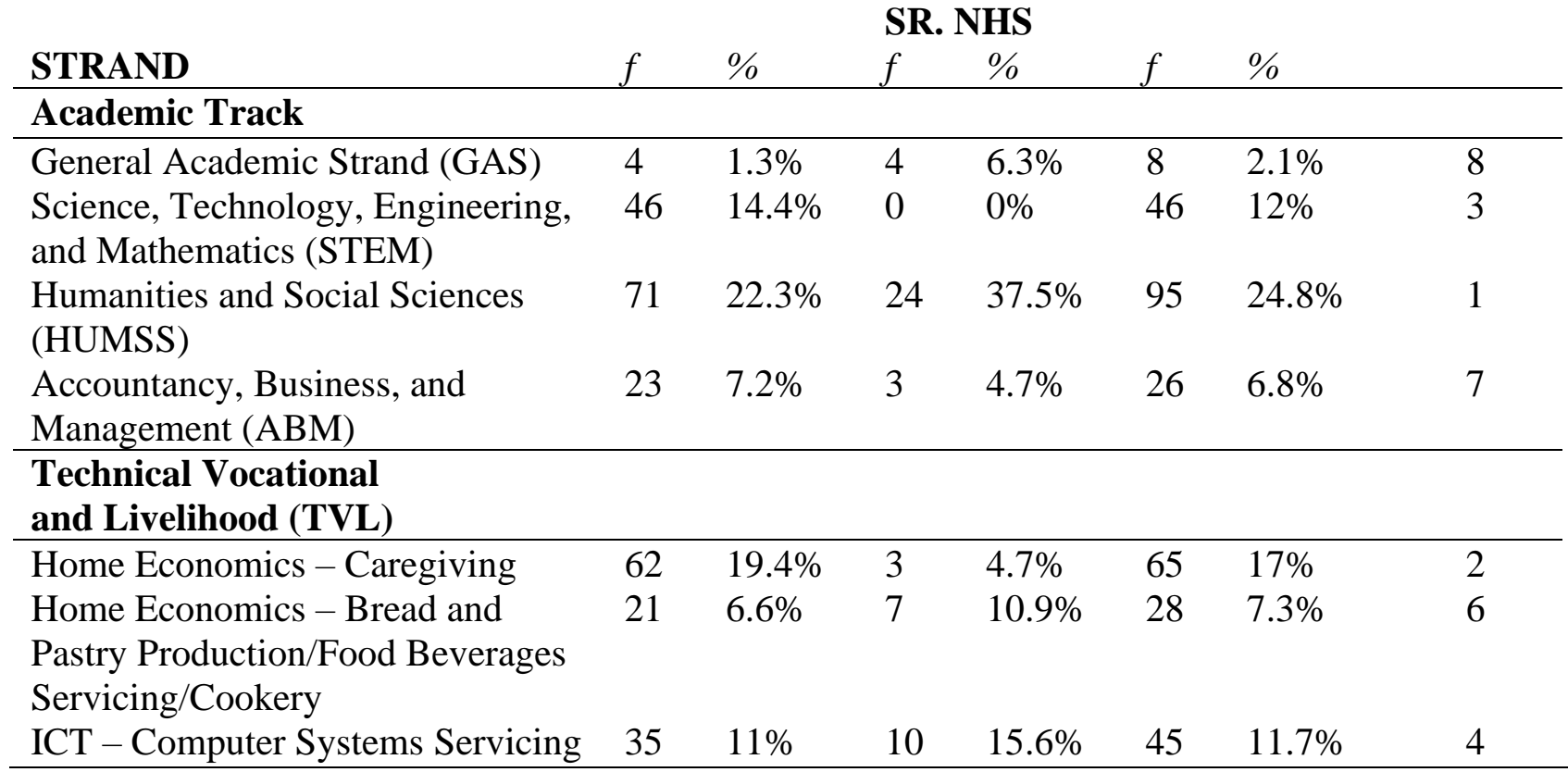

Sapienza: International Journal of Interdisciplinary Studies | Vol. 2 | n. 2 | Abr-Jun | 2021 | e-ISSN: 2675-9780 
ICT - Computer Animation

Industrial Arts - Electrical

Installation and Maintenance

Industrial Arts - Shielded Metal

Arc Welding (SMAW)

\section{Total}

$\begin{array}{llll}0 & 0 \% & 0 & 0 \%\end{array}$

$20 \quad 6.3 \% \quad 6$

$9.4 \%$

$37 \quad 11.5 \% \quad 7$

$10.9 \%$

$319 \quad 100 \% \quad 64 \quad 100 \%$

0
26

$0 \%$

$6.8 \%$

9

7

5

\subsection{Student's SHS Preferred School}

It was evident that Santa Cruz National High School - Senior High School was the preferred school of the majority, which was chosen by 383 (93.2\%) students. Other schools included were Agro Industrial (0.48\%), Cor Jesu College (1.46\%), Polytechnic College of Davao del Sur (0.48\%), University of Mindanao (0.24\%), San Pedro College (0.24\%), Digos City National High School $(0.24 \%)$, and Mary Mediatrix Academy $(0.24 \%)$. It was also noticeable that there were students who did not indicate $(3.42 \%)$ where they want to enroll next school year $2019-2020$.

Table 5. Student's Preferred School

SCHOOL

Sta. Cruz National High School Senior High

Agro Industrial College

Cor Jesu College

Polytechnic College of Davao del

Sur

University of Mindanao

San Pedro College

Digos City National High School

Mary Mediatrix Academy

Not Indicated

\section{COMBINATION}

(STA. CRUZ NHS \& MANUEL FRANCISCO RAMOS SR. NHS )

\begin{tabular}{cc}
\hline$f$ & $\%$ \\
383 & $93.2 \%$ \\
2 & $0.48 \%$ \\
6 & $1.46 \%$ \\
2 & $0.48 \%$ \\
& \\
1 & $0.24 \%$ \\
1 & $0.24 \%$ \\
1 & $0.24 \%$ \\
1 & $0.24 \%$ \\
14 & $3.42 \%$
\end{tabular}

411

$100 \%$

\section{CONCLUSION}

Based on the findings, majority of the grade 10 students both from Santa Cruz National High School - Junior High School and Manuel Francisco C. Ramos Sr. National High School preferred to enroll at Sta. Cruz National High School - Senior High School for school year 2019 2020. Consequently, Humanities and Social Science strand under the Academic Track had the highest number of students preferred this strand over the other strands. Moreover, it was significantly noticeable that most of them preferred to take Technical Vocational Track than Academic Track. That is why one of the reasons of $\mathrm{K}$ to 12 program is to prepare graduates to enter the labor force (Abueva, 2018).

\section{PLAN OF ACTION}

Given the results of the study, the researchers recommended to the Principal to strengthen the Career Guidance in the school especially the parents involvement in the career decision making 
of the students. It should be emphasized during the Parents' Orientation their important role in the chosen career of their children. Aside from the parents' orientation session, it was suggested to create a systematic enrolment process wherein the students will undergo career assessment to better guide the student of what to strand to choose. During the enrolment process, the students will undergo examination, oral interview, and physical and health interview together with their parents. Thus, continues career guidance and implementation of the career guidance modules shall be given to the students for both grade 11 and 12 .

\section{REFERENCES}

Abueva, A. (2018). Why Does the Philippines Need the K-12 Education System? Fonte: soapboxie.com: https://soapboxie.com/social-issues/The-Implementation-o-the-K-12Program-in-the-Philippine-Basic-Education-Curriculum.

Education, D. o. (2015). DepEd Order 41, s. 2015 Senior High School Career Guidance Program and Early Registration. Fonte: DepEd.gov.ph: https://www.deped.gov.ph/2015/08/28/do-41s-2015-senior-high-school-career-guidance-program-and-early-registration-amended-by-do48-s-2015-amendment-to-deped-order-no-41-s-2015-senior-high-school-career-guidanceprogram-and/

Law, B. (1981). Community interaction: a mid-range focus for theories of career development in young adults. British Journal of Guidance and Counselling.

Nuñez, D. (2015). Action Research for Teachers, Social Workers and Practitioners. . Adriana Publishing Co., Inc. .

Parsons, F. (1909). Choosing a vocation. Boston: Houghton Mifflin. 